\title{
劣化度判定結果を活用した 残存耐力評価手法の実栈橋への適用
}

\author{
宇野 州彦1・岩波 光保2 \\ 1 正会員 五洋建設（株） 技術研究所（干329-2746 栃木県那須塩原市四区町 1534-1） \\ E-mail: kunihiko.uno@mail.penta-ocean.co.jp \\ 2 正会員 東京工業大学教授 環境・社会理工学院（干152-8552 東京都目黒区大岡山 2-12-1） \\ E-mail: iwanami@cv.titech.ac.jp
}

\begin{abstract}
栈橋は港湾構造物の中でも特に塩害に対して厳しい環境に置かれており，より適切な維持管理を行って いかなければならないが，劣化した栈橋の残存耐力や耐震性能に関する研究は少ない. また栈橋の残存耐 力を評価する際には詳細定期点検診断が必要となり多大なコストや時間を要するため，特に民間事業者に おいては比較的簡易な耐力評価手法が求められている.

そこで本研究では，各劣化度に応じた試験体の載荷実験を行うことで各劣化度と部材の残存耐力の関係 性を明らかにし，その結果を汎用の構造解析ソフトに導入する簡易な残存耐力評価手法を提案する。実栈 橋を例に劣化度判定結果を構造解析モデルに反映することで, 地震動により損傷が生じる範囲やその程度 を比較的容易にかつ定量的に示すことができた.
\end{abstract}

Key Words : steel pipe piled pier, steel bar corrosion, residual structural performance, maintenance, loading test, numerical analysis

\section{1. はじめに}

高度経済成長期に数多くの社会基盤施設を建設した わが国では, 現在その供用期間が 50 年を超える構造物も 多く, 適切な維持管理は一層重要となってきている，港 湾構造物の中でも栈橋は特に塩害に対して厳しい環境に 置かれており，より適切な維持管理を行っていかなけれ ばならないが，劣化した栈橋の残存耐力や而震性能に関 する研究はあまり多くはない.

栈橋における鉄筋腐食を対象とした残存耐力評価に 関する研究として，著者の一人が港空研資料No.11401)や No.1225 2)，国総研報告No.29年等において栈橋の劣化度と 残存耐力の関係について検討しているが，対象が床版で あり, 梁の劣化度と残存耐力の関係についてはあまり触 れられていない，また港空研報告Vol.47) では栈橋梁を対 象にしているが，局所的な腐食について検討を行ってい るものである. また梁の残存耐力評価としては，文献5) 等において研究が行われているが，対象が一般的な梁で あり，せん断スパン比が比較的小さいとされる栈橋梁を 対象としたものではない.

一方，栈橋の点検・診断に関しては，沿岸技術研究セ ンターの「港湾の施設の維持管理技術マニュアル」6)等 に基づいて，一般定期点検診断および詳細定期点検診断
が通常実施される.栈橋の残存耐力評価を行う場合には, 詳細点検やそれに準じる調査を実施しなければならない が，多大なコストと時間を要するため，特に民間事業者 においては積極的に実施されないのが実状である。

そこで本研究では，一般定期点検診断から得られる劣 化度判定結果から比較的簡易に残存耐力評価を行う手法 について提案し検討を行う。具体的には，各劣化度に応 じた試験体の載荷実験を行い，部材の残存耐力を明らか にした上で，実栈橋を対象に栈橋全体系の残存耐力評価 を行うこととする.

\section{RC 梁部材の載荷実験}

\section{(1) 実験概要}

試験体の概要図を図-1に，セットアップ状況を写真-1 にそれぞれ示す．試験体は実栈橋を参考におよそ $1 / 3$ の 縮尺となるように配筋等を実施した．梁軸方向の主鉄筋 は最下段に D13 を配し，最上段はD10 とし，それ以外の 主鉄筋およびスターラップ筋は D6 とした。 また鉄筋強 度は全て SD345 とした. コンクリートの圧縮強度は全試 験体平均で $30.7 \mathrm{~N} / \mathrm{mm}^{2}$, ヤング係数は全試験体平均で $28.8 \mathrm{kN} / \mathrm{mm}^{2}$ であった. 載荷は純曲げ区間を 400 mm 設け, 
梁中心から $200 \mathrm{~mm}$ 離れた左右の位置に載荷板を設けた. また載荷板から支点までの距離 $(400 \mathrm{~mm})$ と最下段鉄筋か ら上方の梁高さ $(315 \mathrm{~mm})$ の比率であるせん断スパン比に ついては，実際の栈橋でよく見られるような比較的小さ なせん断スパン比としている.

各劣化度に応じた試験体の作製については，電食によ り強制的に最下段鉄筋に腐食を導入した．電食を行った 範囲は支点間の $1200 \mathrm{~mm}$ とした. 腐食に関しては, ファ ラデー則に基づき電流量と腐食量の関係および式験体下 面およひ側面のひび割れ幅を適宜観測し，各劣化度に応 じた試験体を作製した．なお，各試験体における平均腐 食率については, 劣化度 $\mathrm{a}$ 相当試験体 (主鉄筋破断あり) では約 $39 \%$, 劣化度 $\mathrm{a}$ 相当試験体（主鉄筋破断なし）で は約 $26 \%$, 劣化度 $\mathrm{b}$ 相当試験体では約 $17 \%$ ，劣化度 $\mathrm{c}$ 相当試験体では約 $11 \%$ あっった。

なお，実栈橋での劣化度 $\mathrm{a}$ 判定については，その範囲 が非常に広く，軸方向ひび割れが $3 \mathrm{~mm}$ 以上発生してい れば，かぶりの剥落の程度によらず劣化度 $\mathrm{a}$ と判定され る. 剥落のない試験体の結果を実物梁の剥落箇所にも適 用することについては今後検討の余地があるが，本研究 では耐力に大きく影響を与えるのは鉄筋腐食量と考え， かぶり剥落している梁にも実験結果を適用する.

載荷速度については, 載荷開始から荷重 $200 \mathrm{kN}$ となる 変位もしくは傾きに変化が現れるまでは $0.005 \mathrm{~mm} / \mathrm{sec}$ つ載荷を行った．その後は, 変位が $10 \mathrm{~mm}$ 発生するまで は $0.02 \mathrm{~mm} / \mathrm{sec}$ ずつ載荷し，それ以降は $0.05 \mathrm{~mm} / \mathrm{sec}$ ずつ 載荷を行った。

\section{（2） 実験結果}

載荷実験より得られた試験体の荷重一変位関係を図-2 に示寸. 結果から劣化度の違いにより, 降伏荷重や最大

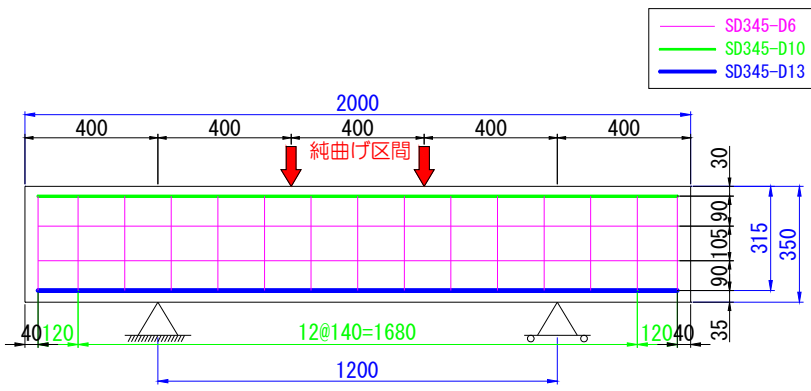

図-1 試験体概要図 (単位 : mm)

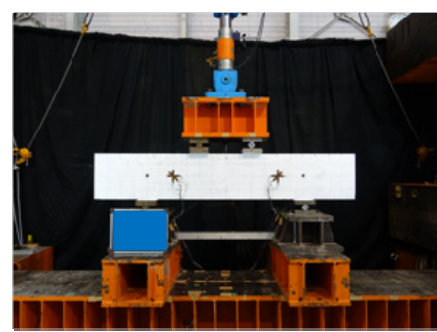

写真-1＼cjkstart試験体セットアップ状況
荷重の值に差が生じている.ここで降伏荷重の值と健全 試験体に対寸る耐力比を表-1 に示寸．降伏荷重の定義は, 載荷時にスパン中央変位が急増したところとした．健全 試験体と比較して劣化度 $\mathrm{c}$ 相当となる試験体では残存耐 力が約 9 割，劣化度 $\mathrm{b}$ 相当となる試験体では残存耐力が 約 8 割，主鉄筋破断なしの劣化度判定 $\mathrm{a}$ 相当となる試験 体では残存耐力が約 6 割程度となった. 既往の研究 2),3) では，劣化度 $\mathrm{a}$ 相当では健全状態に比べて耐力が $4 \sim 5$ 割程度低減すると示されていることから, 劣化度 a $の$ 判 定が広範囲であることを考えるとこれらの研究結果とも 比較的整合寸る．また主鉄筋に破断がある場合には，残 存耐力が約 3 割程度と著しく低下寸る結果となった. こ れは既往の文献 4)でも指摘されているところである．主 鉄筋3本のうち2本が載荷前に破断している状況であり, 主鉄筋の破断比率がある程度そのまま残存耐力に反映さ れた結果であると示唆される．また，荷重一変位関係に おいて降伏に至るまでの変位（0５ mm）を拡大したも のを図-3に示寸. 図のように, 降伏に至るまでの剛性 (傾 き）も，降伏值の違いと同様に異なることが分かる.

また最大荷重を示した後の変形性能にも各試験体で 違いが現れた．劣化度 $\mathrm{c}$ または劣化度 $\mathrm{b}$ 相当では, 最大 耐力発揮後も比較的変形性能があることが示されたが,

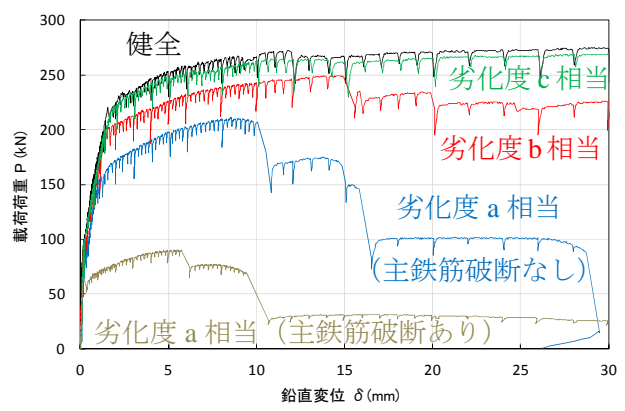

図-2＼cjkstart試験体の荷重一変位関係

表-1 試験体の降伏荷重と而的力比

\begin{tabular}{c|c|c}
\hline 試験体 & 降伏荷重 $(\mathrm{kN})$ & 健全状態に対する耐力比 \\
\hline 健全 & 230 & - \\
\hline 劣化度c相当 & 217 & 0.94 \\
\hline 劣化度b相当 & 194 & 0.84 \\
\hline 劣化度a相当 & 146 & 0.63 \\
\hline $\begin{array}{c}\text { 劣化度a相当 } \\
\text { (主鉄筋破断あり) }\end{array}$ & 72 & 0.31 \\
\hline
\end{tabular}

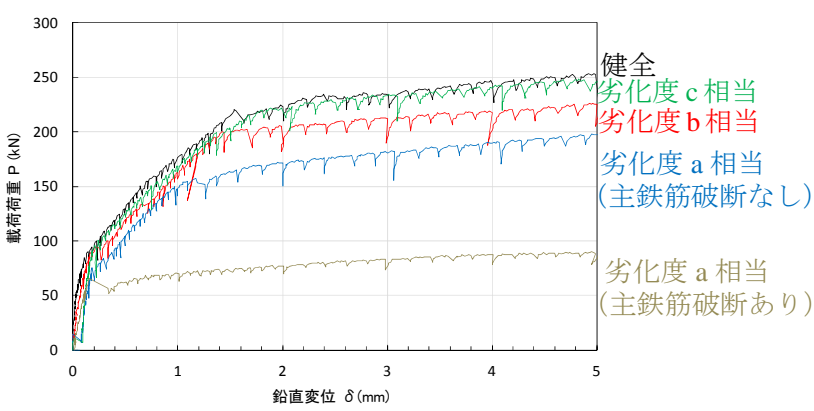

図-3 載荷初期段階における荷重一変位関係 


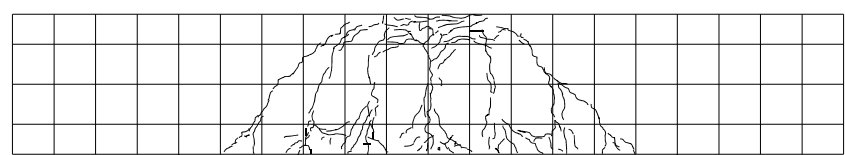

(a) 健全試験体

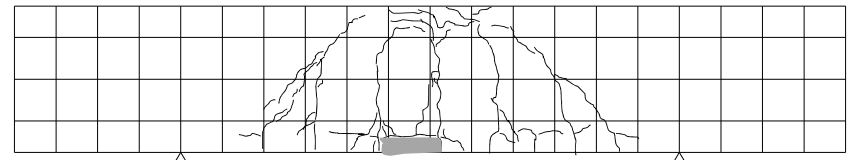

(b) 劣化度 $\mathrm{c}$ 相当試験体

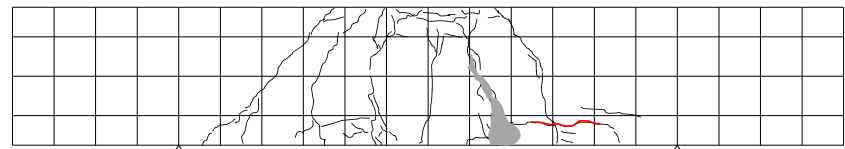

(c) 劣化度 $\mathrm{b}$ 相当試験体

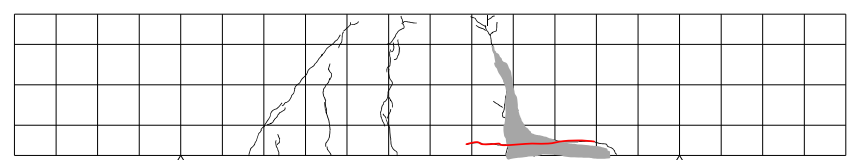

(d) 劣化度 $\mathrm{a}$ 相当試験体（主鉄筋破断なし）

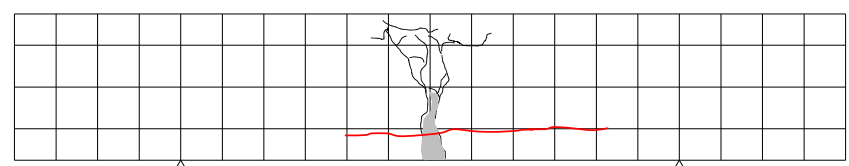

(e) 劣化度 $\mathrm{a}$ 相当試験体（主鉄筋破断あり）

図-4 各試験体のひび割れスケッチ (ハッチングは剥落箇所)

劣化度 $\mathrm{a}$ 相当では変位が $10 \mathrm{~mm}$ 程度発生したところで急 激な荷重低下が示された。 しかし降伏変位の 9 10 倍程 度となることから, 設計上この時点での荷重低下は問題 ないと考えられる. したがって, 劣化度 $\mathrm{a}$ 相当であって も，主鉄筋の破断がなく，降伏荷重または最大荷重があ る程度発揮されるのであれば，設計上，剛性の低減はす るものの劣化度 $\mathrm{b}, \mathrm{c}$ 相当と同様に塑性領域まで見ること ができると考えられる，ただし，本研究ではそれぞれの 劣化度に対して試験体を 1 体の久載荷した結果であるた め, より精度のよい劣化度と耐力の相関性については, 多くの載荷結果が必要であると考えている. また図-4に, 各劣化度相当の試験体における最終変形時のひび割れス ケッチを示す. 載荷前の腐食ひび割れについては赤色で 示す. 図より, 健全試験体から劣化度 $\mathrm{b}$ 相当試験体まで は, 支点付近にまで広範囲にひび割れが発生するものの, 鉄筋腐食率が大きくなるにしたがって，より局所的にひ び割れが生じていること，またひび割れ本数が減少する ことが確認できる.さらに鉄筋破断のある場合には，破 断箇所近傍にひび割れが集中していた。 このことは既往 の研究 5) と概ね致する結果である.

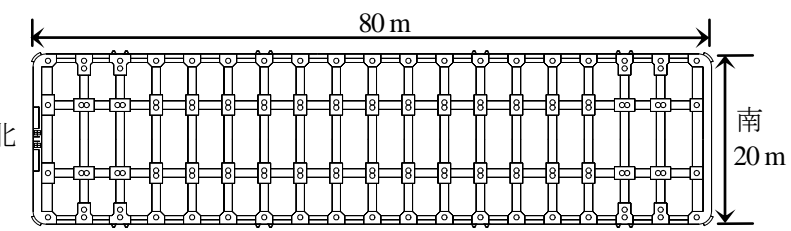

図-5 対象栈橋平面図

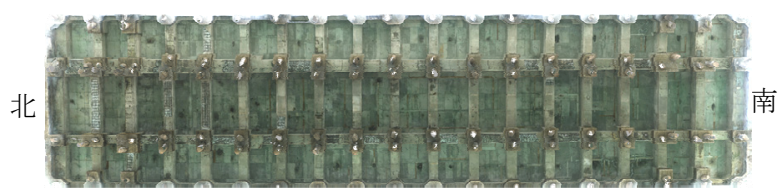

図-6＼cjkstart栈橋の 3D モデル

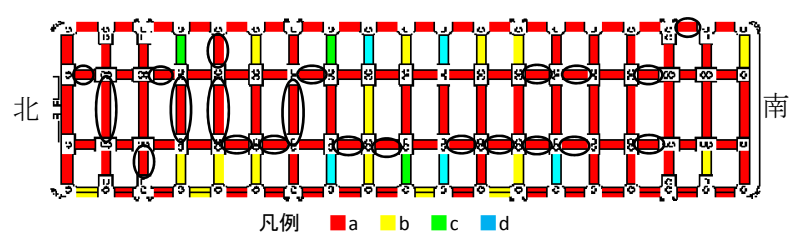

図-7 劣化度判定結果

\section{3. 実栈橋の劣化度調査}

\section{（1）実栈橋概要と劣化度調査方法}

今回検討対象とした実栈橋の平面図を図-5に示す。上 部工は長さが約 $80 \mathrm{~m}$, 幅が約 $20 \mathrm{~m}$ で斜杭を有しており, 建設から約 50 年が経過している. 劣化度調査は無線LAN ボート7を使用して実施した。撮影された写真から, SfM/MVS（Structure from Motion / Multi View Stereo）解析 で3D モデルを作成した．得られた 3D モデルを図-6に 示す。画像データとしては，合計で約 2,000 枚の画像 (3,840×2,160 画素) を使用している.

\section{(2) 劣化度判定結果}

梁の劣化度判定を行った結果を図-7 に示寸. 劣化度判 定は，文献 6に基づき実施した．なお，床版についても 判定可能であるが, 本研究では梁に着目していること, また床版は今回の解析モデルでは考慮していないことか ら，掲載を省略している，なお，図中の梁に丸印を付け ている箇所については，梁下面のかぶりがほとんど剥落 して鉄筋が露出しており，腐食による主鉄筋の大幅な断 面減少や主鉄筋破断の可能性がある梁である。今回は写 真での夕判定しているため, 主鉄筋破断についてはあく まで可能性としている. 実際の破断の有無やその程度に ついては別途調査が必要であると考えるが，本研究では あくまで簡易な点検から判断することを主眼に置いてい るため, 主鉄筋破断の可能性のある箇所については, 次 章での解析において考慮するケースを別途設けることと する. 以上の判定結果を基に, 次章において栈橋全体系 の残存耐力評価を実施することとする. 


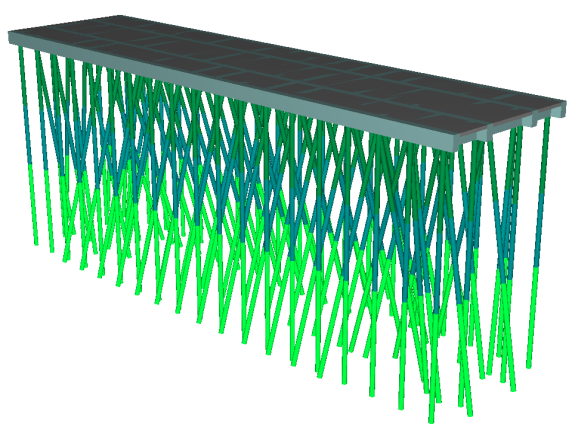

図-8＼cjkstart解析モデル概観図

\section{4. 劣化度判定結果を活用した残存耐力評価 手法}

\section{(1) 解析モデル概要}

今回検討対象とした実栈橋の解析モデルを図-8 に示 す. 解析コードは (株) FORUM8 の Engineer's Studio (Ver.7.0.0)を用いている. 各材料の物性值については表-2 に示寸. 図-8における杭色の違いは, 表-2 に示寸肉厚の 違いを表している. 鋼管杭はファイバー要素でモデル化 した. 鋼管杭の劣化については，今回劣化度調查を実施 していないことから，港湾基準 ${ }^{8}$ に基づいて鋼材の腐食 速度の標準值を用い, 表-2 に示寸物性值から鋼管杭の肉 厚を減少させている. 具体的には, L.W.L -1 m より上方 を $1.5 \mathrm{~mm}$, それ以下の海水中を $1.0 \mathrm{~mm}$, 海底の土中部 を $0.15 \mathrm{~mm}$ それぞれ減肉している. なお梁については次 節にて説明するが，劣化度に応じた骨格モデルを規定す るため, M- $\phi$ 関係を規定する骨格曲線を有する非線形は り要素としてモデル化する. なお鋼管杭と梁は剛結合と している. また図-8では床版をモデル化しているように 見えるが，形状のみを入力し岡性は入力していない，床 版重量の夕床版を支持する 4 本の梁に分担させている. 鋼管杭に関して, 仮想地表面以深においては, 地盤の影 響を受けることから，地盤ばねをモデル化し，杭に接続 している.

今回使用した入力地震動を図-9 に示寸. 本研究では, レベル 1 地震動相当およびレベル 2 地震動相当の地震が 作用した場合に, 劣化した栈橋がどのような挙動を示す のか，また栈橋のどの領域に損傷が生じるのかについて 検討を行うこととした. レベル 1 地震動として国土技術 政策総合研究所港湾施設研究室 HP に掲載されている地 震動のうち, 対象栈橋の立地場所近傍の地震動デー夕を 使用した. またレベル 2 地震動としては兵庫県南部地震 においてポートアイランドにてアレー観測された地震波 を使用した. 入力方向は, 栈橋の長辺方向または短辺方 向の各 1 方向入力と, 2 方向同時入力の計 3 ケースを各 地震動において実施した. 解析ステップ (時間刻み) は 0.001 秒とした.
表-2 解析物性值

\begin{tabular}{|c|c|c|c|c|}
\hline \multirow{10}{*}{$\begin{array}{c}\text { 梁 } \\
\text { 幅 : } 1000 \mathrm{~mm} \\
\text { 高さ : } 1800 \mathrm{~mm}\end{array}$} & コンクリート & 設計基淮強度 & \multicolumn{2}{|c|}{$24 \mathrm{~N} / \mathrm{mm}^{2}$} \\
\hline & 鉄管 & 強度 & \multicolumn{2}{|r|}{ SD295 } \\
\hline & \multirow{8}{*}{ 配笳 } & \multirow{2}{*}{ 長辺端部梁 } & 上筋 & D22-8本 \\
\hline & & & 下筋 & D22-8本 \\
\hline & & \multirow{2}{*}{ 長辺中央梁 } & 上筋 & D25-7本 \\
\hline & & & 下筋 & D25-17本 \\
\hline & & \multirow{2}{*}{ 短辺端部梁 } & 上筋 & D16-5本 \\
\hline & & & 下筋 & D22-5本 \\
\hline & & \multirow{2}{*}{ 短辺中央梁 } & 上筋 & D29-5本 \\
\hline & & & 下筋 & D25-9本 \\
\hline \multirow{4}{*}{$\begin{array}{c}\text { 鋼管杭 } \\
\text { 杭径: } 609.6 \mathrm{~mm}\end{array}$} & 材質 & & SKK400 & \\
\hline & \multirow{3}{*}{ 肉厚変化 } & $\begin{array}{l}+3.70 \mathrm{~m} \sim-5.30 \mathrm{~m} \\
\end{array}$ & \multirow{2}{*}{\multicolumn{2}{|c|}{$16.0 \mathrm{~mm}$}} \\
\hline & & $-5.30 \mathrm{~m} \sim-14.30 \mathrm{~m}$ & & \\
\hline & & $-14.30 \mathrm{~m} \sim$ & \multicolumn{2}{|r|}{$9.5 \mathrm{~mm}$} \\
\hline \multirow{5}{*}{ 地盤ばねね } & \multirow{5}{*}{ ばね定数 } & $-9.14 \mathrm{~m} \sim-10.50 \mathrm{~m}$ & \multicolumn{2}{|c|}{ ばねなし } \\
\hline & & $-10.50 \mathrm{~m} \sim-14.50 \mathrm{~m}$ & $30,000 \mathrm{kN} / \mathrm{m}^{3}$ & 上限值 : $1440 \mathrm{kN} / \mathrm{m}^{2}$ \\
\hline & & $-14.50 \mathrm{~m} \sim-19.70 \mathrm{~m}$ & $150,000 \mathrm{kN} / \mathrm{m}^{3}$ & 上限なし \\
\hline & & $-19.70 \mathrm{~m} \sim-25.20 \mathrm{~m}$ & $90,000 \mathrm{kN} / \mathrm{m}^{3}$ & 上限値 : $8640 \mathrm{kN} / \mathrm{m}^{2}$ \\
\hline & & $-25.20 \mathrm{~m} \sim$ & $150,000 \mathrm{kN} / \mathrm{m}^{3}$ & 上限なし \\
\hline
\end{tabular}

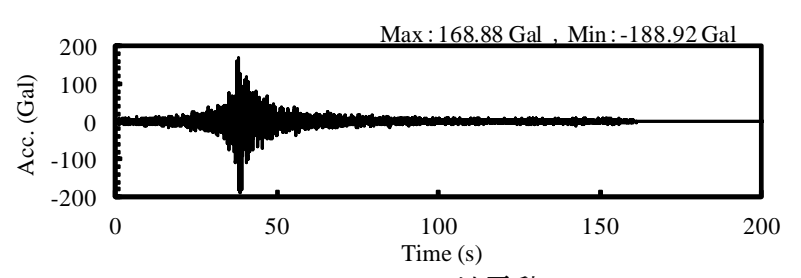

(a) レベル 1 地震動

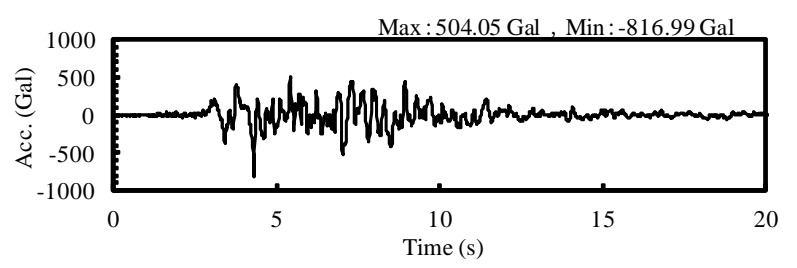

(b) レベル 2 地震動

図-9 入力地震動

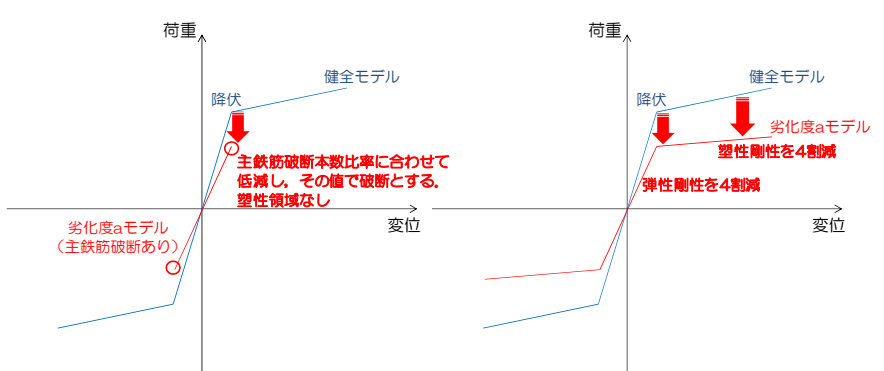

(a) 劣化度 $\mathrm{a}$ 相当(破断あり)

(b) 劣化度 $\mathrm{a}$ 相当(破断なし)

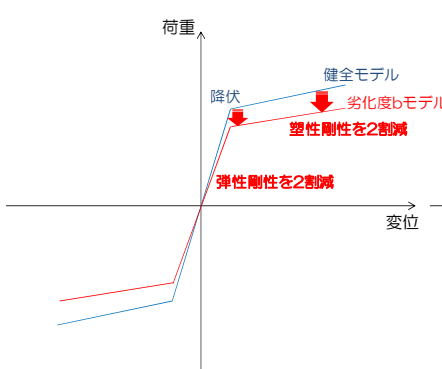

(c) 劣化度 $b$ 相当

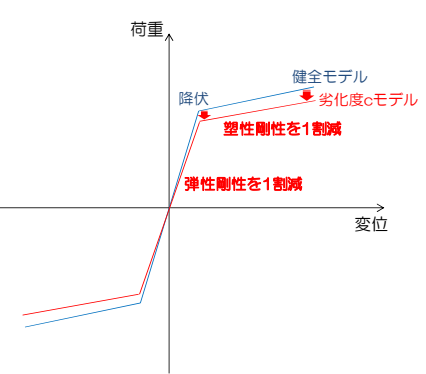

(d) 劣化度 $\mathrm{c}$ 相当
図-10 各劣化度に応じた骨格モデル

\section{（2）各劣化度に応じた梁部材の骨格モデルについて}

前章の実験結果を踏まえて，各劣化度に応じた梁部材 の骨格モデルについて，図-10 のような骨格低減モデル を本研究で提案する. 劣化度 $\mathrm{a}$ 相当では, 健全状態にお 
ける骨格モデルに対して，弾性領域および塑性領域のい ずれも 4 割低減するモデルとする. 劣化度 $\mathrm{b}$ 相当では, 弾性領域および塑性領域のいずれも 2 割低減, 劣化度 c 相当では，弾性領域および塑性領域のいずれも 1 割低減 のモデルでそれぞれ設定することとする．また劣化度 a 相当のうち, 主鉄筋破断の可能性のある部材については, 主鉄筋の破断本数比率に合わせて降伏荷重および弾性剛 性を低減することとし，塑性領域については考慮せず, 設定した低減降伏荷重となる時点で終局状態となるモデ ルとする．なお，載荷実験においては梁に鉛直下向きの 荷重を作用させて得られた結果を反映させているため, それ以外の方向（鉛直上向き，水平方向）については本 来別途載荷実験が必要であるが，本検討では安全側の評 価のため，全ての方向において低減骨格モデルを適用す ることとする．なお，各方向における骨格モデルの検討 については今後の課題である. またスターラップも劣化 した場合にはせん断耐力も低下寸ることが考えられるが, 本検討では曲げ耐力の低下に着目し，せん断耐力低下の 考慮については今後の課題と考えている.

\section{(3) 解析結果}

解析結果を以下に示す.ここでは主鉄筋破断の可能性 のある箇所においても，主鉄筋破断なしとして解析を行 っている. なお，主鉄筋破断の検討については，次節に て行うこととする. また本検討では，栈橋の地震時変形 よりも部材の地震時損傷に焦点を当てているので，基本 的には梁部材または杭部材の損傷程度やその範囲を中心 に述べることとする.

\section{a) レベル 1 地震動}

レベル 1 地震動を入力した際の梁の損傷を図-11 に示 す. 鋼管杭の損傷はほとんど見られなかったため梁のみ 掲載している．梁については栈橋端部において曲げひび

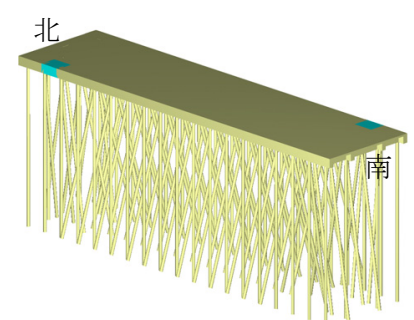

(a) 長辺方向入力

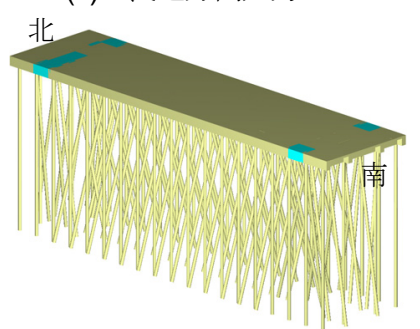

(c) 2 方向同時入力 (b) 短辺方向入力
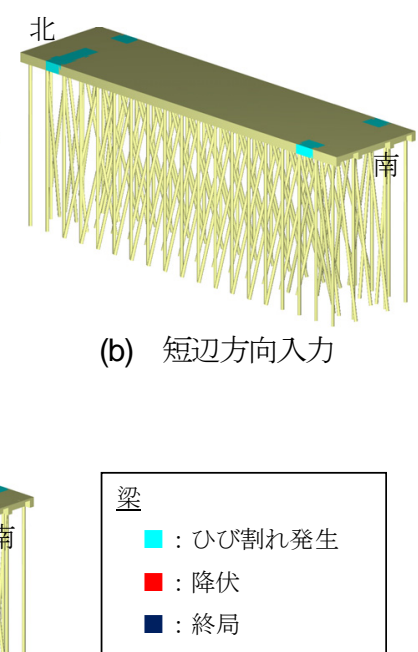

図-11 梁の損傷状況（レベル1 地震動）

割れ損傷が見られた。降伏には至っていないものの，降 伏モーメント（約 $2000 \mathrm{kN} \cdot \mathrm{m} ）$ の約 8 割程度の断面力 が発生している箇所もある。ただちに供用停止というわ けではないが，ひび割れ補修等が必要である可能性があ る. なお，今回考慮していない床版にもハッチングがな されているが，これは隣接する梁が損傷を示した場合に 合わせて表示するようにしている，以降も同様である.

\section{b) レベル 2 地震動}

レベル 2 地震動を入力した際の鋼管杭および梁の損傷 を図-12，図-13 にそれぞれ示す。結果から栈橋の多くの 箇所において降伏荷重を超えていることが確認できた. 例えば梁においては最大発生モーメントが降伏の約 1.1 倍であった．梁の劣化度 $\mathrm{a}$ 判定が広範囲であることに比 へ，梁の地震時損傷（降伏箇所）が限定的である理由と しては，対象栈橋が斜杭構造であることから地震時の栈 橋変位量が小さいためであると考えられる.

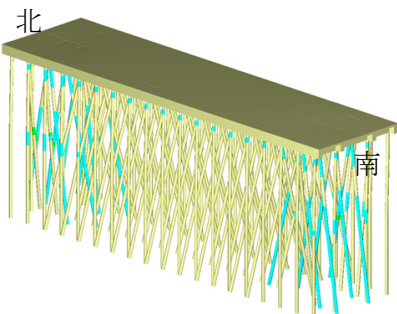

(a) 長辺方向入力

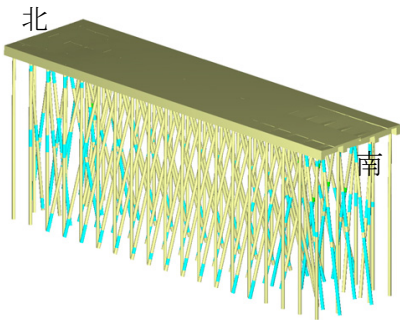

(c) 2 方向同時入力

図-12＼cjkstart鋼管杭の損傷状況（レベル 2 地震動）

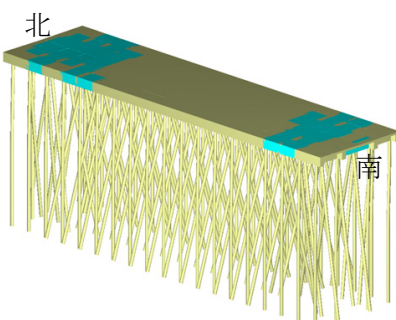

(a) 長辺方向入力

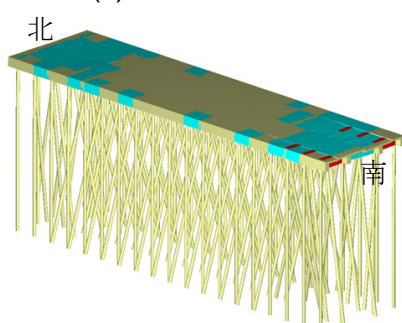

(c) 2 方向同時入力

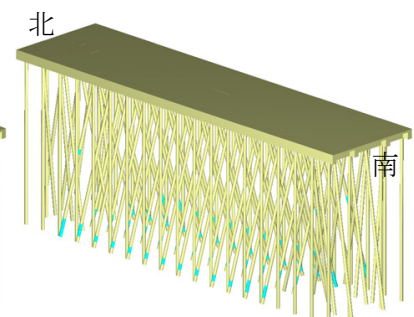

(b) 短辺方向入力

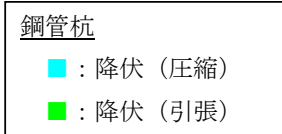

図-13 梁の損傷状況（レベル 2 地震動） 


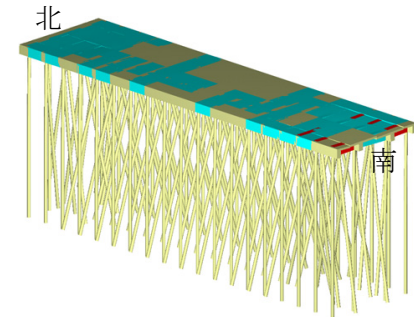

(a) 梁の損傷状況

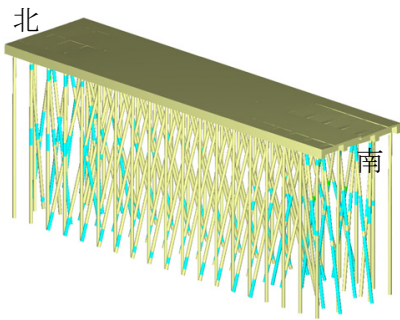

(b) 鋼管杭の損傷状況
図-14 主鉄筋破断を考慮した栈橋の損傷状況 （レベル 2 地震動 2 方向同時入力）

\section{（4）主鉄筋の破断が見られる場合の残存耐力評価}

本節では主鉄筋破断の可能性のある箇所について，図 -10 に示している主鉄筋破断の骨格モデルを適用し，そ の影響を検討することとする，本節では，レベル 2 地震 動を 2 方向同時入力したケースのみ述べることとする.

解析結果を図-14 に示寸，凡例は図-12, 図-13 と同様 である．降伏箇所の違いはあまりないものの，曲げひび 割れ損傷箇所が拡大していることが分かる，先述したよ うに地震時変位量が小さいことから降伏に至る箇所は少 ないものの, 栈橋全体において断面力の再配分により, 損傷箇所が拡大したものと考えられる.

\section{5. まとめ}

本研究では，劣化度判定結果から比較的簡易に残存耐 力評価を行う手法について提案し, 実栈橋への適用を通 して検討を行った。これまでは栈橋の残存耐力を評価す るために多大な時間とコストを要してきたが，本提案を 用いることで，より簡易に損傷箇所やその損傷度をある 程度把握できる可能性がある。また，本研究では斜杭式 栈橋を例に検討を実施したが，直杭式栈橋の場合では， 地震時変位量が大きくなる可能性があり，多くの梁で降 伏または終局に至った可能性も示唆される.
しかしながら，本研究においては骨格曲線等をはじめ 多くの仮定を行っているため, 課題がいくつか残されて いる. まず本研究では曲げ耐力の低下に着目して研究を 実施しているが，スターラップも同様に劣化することか らせん断耐力の低下による影響とその考慮も課題として 挙げられる．またコンクリート下面のかぶりが剥落した 場合に特に杭頭付近に見られる曲げ圧縮作用時（鉛直上 向きに荷重が作用する場合）においては，そのかぶり剥 落の影響が耐力に影響寸るものと考えられる。これは劣 化骨格曲線の正側・負側のそれぞれの設定にも影響して くるところであり，今後検討を行いたいと考えている.

\section{参考文献}

1) 加藤絵万, 岩波光保, 山路徹, 横田弘：建設後 30 年 以上経過した栈橋上部工から切り出した RC 部材の劣 化性状と構造性能, 港湾空港技術研究所資料, No.1140, 2006.

2) 加藤絵万，川端雄一郎，岩波光保 : 港湾 RC 構造物の 確率論に基づく保有性能評価，港湾空港技術研究所資 料, No.1225, 2010.

3）高橋宏直，横田弘，岩波光保 : 港湾施設のアセットマ ネジメントに関する研究 一構造性能の低下予測と アセットマネジメントの試行例一, 国土技術政策総合 研究所研究報告，No.29，2006。

4) 加藤絵万, 濱田洋志，岩波光保，横田弘：局所的に生 じた鉄筋腐食が RC はりの構造性能に及ぼす影響, 港 湾空港技術研究所報告，Vol.47，2008.

5）土木学会：コンクリート技術シリーズ，続・材料劣化 が生じたコンクリート構造物の構造性能，2009。

6) (財)沿岸技術研究センター：港湾の施設の維持管理技 術マニュアル，沿岸技術ライブラリーNo.26， 2007.

7) 水野剣一, 酒井貴洋, 小笠原哲也, 杉本英樹, 本山昇 : ラジコンボートを用いた栈橋下面部の点検・診断シス テムの開発，土木学会論文集 B3 (海洋開発), Vol.73, No.2, pp.I_432-I_437, 2017.

8） (社)日本港湾協会 : 港湾の施設の技術上の基準・同解 説, 2007.

(2018.2.8 受付)

\section{EVALUATION METHOD OF RESIDUAL STRUCTURAL PERFORMANCE BASED ON THE JUDGMENT RESULT OF DETERIORATION DEGREES AND ITS APPLICATION TO CORRODED PIER}

\section{Kunihiko UNO and Mitsuyasu IWANAMI}

Further maintenance should be conducted for pier due to its vulnerability towards chloride induced deterioration. However, research for residual structural performance and seismic performance of corroded pier is still limited. Since significant cost and time is needed for regular detailed survey to evaluate the residual structural performance of corroded pier, relatively simple evaluation method becomes necessary, especially for private businesses. In this research, load tests for specimens with different deterioration degrees are conducted, relationship between deterioration degree and residual structural performance is clarified. Introducing the results of the tests to versatile structural analysis software, simple evaluation method of residual structural performance is proposed. By reflecting the judgment result of deterioration degrees of a real corroded pier to structural analysis model, seismic damage area and level could be relatively easily and quantitatively shown. 